fertilizers]. Collection of scientific works of the Podilsky state agricultural and technical academy. Kamyanets-Podilsky: Abetka, 9, 140-142.

4. Radchenko, M. V., Butenko, A. O., \& Hlupak, Z. I. (2018). Vplyv systemy dobryv ta efektyvnist' rehulyatora rostu na produktyvnist' hrechky v umovakh pivnichno-skhidnoho lisostepu Ukrayiny [The influence of fertilizer system and efficacy of growth regulator on buckwheat productivity under the conditions of north-east forest steppe of Ukraine]. Ukrainian Journal of Ecology, 8(2), 89-94. doi: http://dx.doi.org/10.15421/2018_314 (Web of Science (Emerging Sources Citation Index).

5. Trotsenko, V. I., \& Ilchenko, V. O. (2013). Vrozhaynist' okroplenykh sortiv vivsa zalezhno vid mineral'nykh dobryv ta bakterial'noho preparatu [The yield of hulled oats varieties depending on mineral fertilizers and bacterial preparation]. Visnyk of Sumy NAU, series "Agronomy and Biology», 11 (26), 96-100.

6. Sharafetdinov, U. I. (2003). Vplyv biolohichnykh preparativ na vrozhaynist' ta yakist' zerna yaroyi pshenytsi $v$ umovakh Volho-Vyat's'koyi oblasti [Influence of biological preparations on yield and quality of grain of spring wheat in the conditions of the Volgo-Vyatka region]: PhD dissertation 06.01.09 «Plant production». Nizhniy Novgorod.

7. Shevchenko, A. O. (1998). Rehulyatory rostu. Pryntsypovo novyy i vysokoefektyvnyy element sil's'kohospodars'koyi tekhniky [Regulators of growth. Fundamentally new and highly effective element of agricultural technology]. Plant protection, 1, 17-19.

\title{
EFFECT OF THE CULTIVATION OF LEGUMES ON THE DYNAMICS OF SOD-PODZOLIC SOIL FERTILITY RATE
}

\section{Alina Hrechykhina ${ }^{1}$ Yana Yatsyshina ${ }^{2}$}

DOI: https://doi.org/10.30525/978-9934-588-11-2_4

In order to preserve and increase soil fertility, as well as to increase agroecological resistance to adverse anthropogenic factors, it is essential to accumulate organic matter in the soil. Due to the sharp decrease in the number of livestock in the farms of Ukraine, it is almost impossible to address this problem only by introducing manure. Therefore, it is necessary to find ways to restore and maintain the optimal level of soil fertility by means of the application of alternative methods of accumulation in the soil. One of the main resources and promising direction in solving this problem can be the cultivation of perennial legumes [3, p. 106-110].

Perennial legumes are one of the factors, which enable to stabilize the processes occurring in the soil - plant - animal - human system. A large phytomeliorative role of perennial legumes on the arable land, the optimal ratio of plowed land, hayfields and pastures will contribute to the elimination of destructive processes that occur in agricultural landscapes, reduce erosion and increase soil fertility and crop yields [4, p. 18-21; 7, 30-34].

${ }_{2}^{1}$ Sumy Building College, Ukraine 
It should be noted that perennial legumes improve the fertility of soil, protect it from wind and water erosion, leave dry roots and nutrient residues in the soil (from 40 to $100-120 \mathrm{~kg} / \mathrm{ha}$ ). Their root system contains between $2.5-3$ and $4 \%$ nitrogen (per dry substance). After its dying and decomposition, nitrogen stocks in the soil increase by $150-200$, sometimes $300 \mathrm{~kg} / \mathrm{ha}$. Accumulated in the root system and crop residues of leguminous crops, nitrogen in the soil is well absorbed by other crops involved in rotation [2, p. 53-57].

The scientists claim that the use of leguminous crops, perennial grasses that can improve soil fertility and form high yields in crop rotations facilitate a solution to the issue of providing livestock feed and organic fertilizers - crop production. Therefore, most farms develop these important agricultural sectors from a comprehensive perspective.

At the same time, perennial grasses enrich the soil with organic matter and biological nitrogen, which stabilizes its fertility. The manufacture of their products is economically justified [5, p. 9].

Nitrogen is an important element for plant growth and development. Perennial grasses, especially legumes, in terms of nitrogen accumulation in the soil, are a very good precursor to many major cultivated plants [1, p. 391-393].

According to the calculation of scientists, in the conditions of the Central ForestSteppe of Ukraine alfalfa for three years of life is able to absorb from the air $735 \mathrm{~kg} / \mathrm{ha}$ of nitrogen, enriching the soil in the amount of $598 \mathrm{~kg}$ per 1 hectare [6, p. 54-57].

The soil cover of the experimental field is represented by sod-podzolic surfacegleyed soil on the slope of the north-western exposure with steepness of 1-3 $3^{\circ}$. Prior to the sowing of legumes, the research plot was characterized by the following indicators: humus content $-2.4 \%$ (low), alkaline hydrolyzed nitrogen $-67.1 \mathrm{mg} / \mathrm{kg}$ of soil (very low), mobile phosphorus $-75.6 \mathrm{mg} / \mathrm{kg}$ of soil (medium), exchangeable potassium $-66.0 \mathrm{mg} / \mathrm{kg}$ of soil (low). The soil reaction was very acidic and acidic ( $\mathrm{pH}$ of the salt extract is 4.4-4.8), hydrolytic acidity - 5.8-6.0 mg-EQ per 100g of soil. The amount of calcium absorbed in the soils was $6.3 \mathrm{mg}-\mathrm{EQ}$, magnesium $2.5 \mathrm{mg}$-EQ per $100 \mathrm{~g}$ of soil, indicating low base saturation.

The scheme of two-factor experiment provides for the three levels of fertilizing. Mineral fertilizers were applied at-ground in the form of ammonium nitrate, granulated superphosphate and double manure salt in early spring. The size of seedling plots was $15 \mathrm{~m}^{2}$, accounting plots $-10 \mathrm{~m}^{2}$. In addition, perspective varieties of legumes such as cow clover - Darunok, alsike clover - Rozheva 27, birdsfoot deer vetch - Aiaks, alfalfa - Andi, were sown and released.

A positive effect of the cultivation of legumes on the rate of fertility of sodpodzolic soil has been established on the basis of the conducted research. The results of experiments have shown that the long-term cultivation of perennial legumes on nutrient-poor soils results in the development of a highly branched root system. As a result, the weight of the root and stubble residues exceeds the weight of the aboveground mass or approaches it. Thus, the yield of the above-ground herb mass for two years of use has amounted to $14.6 \mathrm{c} /$ ha of air dry matter, and the yield of legumes $14.2 \mathrm{t} / \mathrm{ha}$. The root and stubble residues are amounted to 165.3 and $132 \mathrm{c} / \mathrm{ha}$, 
respectively. With a well-developed root mass, a large amount of nitrogen remains in the soil (231.4 and $145.2 \mathrm{~kg} / \mathrm{ha}$, respectively), which largely (about 50-70\%) compensates for the expenditure of soil nitrogen to form a yield of herbs.

It has been established that the productivity of perennial legumes on average during the years of research with the two-haying use on the variants without fertilizers and with the application of $\mathrm{Ph}_{60} \mathrm{P}_{60}$ is in the range of 5.03-of $6.47 \mathrm{t} / \mathrm{ha}$ of dry weight, $3.62-4.98 \mathrm{t} / \mathrm{ha}$ of fodder units, $0.79-1.08 \mathrm{t} / \mathrm{ha}$ of crude protein, $43.3-58.2 \mathrm{GJ} / \mathrm{ha}$ of exchange energy.

The highest content of alki-hydrolyzable nitrogen is observed in the soil when growing alfalfa $-80.4 \mathrm{mg} / \mathrm{kg}$ of soil, due to the productive activity of symbiotic nitrogen-fixing bacteria of this species of herbs. The nitrogen content in the soil under cow clover was $4.8 \%$ lower and amounted to $77.0 \mathrm{mg} / \mathrm{kg}$ of soil. The other experimental plots had almost the same nitrogen content $-77.5-77.8 \mathrm{mg} / \mathrm{kg}$ of soil that was 3\% less compared to the variant under alfalfa. When applying phosphoruspotassium fertilizers on the variants of alfalfa $+\mathrm{Ph}_{60} \mathrm{P}_{60}$ and alfalfa $+\mathrm{Ph}_{90} \mathrm{P}_{90}$, the nitrogen index increased by $10.6 \mathrm{mg} / \mathrm{kg}$ of soil. On all variants of the experiment the content of alkaline hydrolyzed nitrogen was very low.

The content of mobile phosphorus on the experiment variants ranged from 80.9 to $83.2 \mathrm{mg} / \mathrm{kg}$ of soil (average level) depending on the crop. It has been established that the cultivation of cow clover, alsike clover, birdsfoot deer vetch, alfalfa against $\mathrm{Ph}_{90}$ during the study period contributed to the growth of mobile phosphorus in comparison with its content in the soil prior to the sowing of herbs by $4.2-5.9 \%$, in particular, in the variant with alfalfa it was amounted to $5.0 \mathrm{mg} / \mathrm{kg}$ of soil. This is due to the fact that the stockpile of phosphorus in the soil is the most stable among other indicators of fertility, and the creation of cover with perennial herbs with a developed root system contributes to the suspension of erosion processes, the content of mobile phosphorus in the soil increases.

Characterizing the balance of nutrients of sod-podzolic soil subject to the cultivation of legumes, the analysis of nitrogen expenditure has shown that this element of nutrition is most heavily used by birdsfoot deer vetch and cow clover - the yield is 105.4 and $100.3 \mathrm{~kg} / \mathrm{ha}$, respectively. This is due to the high productivity of these crops. The lowest nitrogen losses are found in alfalfa $-98.6 \mathrm{~kg} / \mathrm{ha}$ that correlate with the lowest productivity of that variant. The rate of biological nitrogen entering the soil is largely dependent on the efficiency of nitrogen fixation. The highest nitrogen intake from nitrogen fixation is recorded on the variant with birdsfoot deer vetch $-140.8 \mathrm{~kg} / \mathrm{ha}$, and the lowest - on the variant with alsike clover $-91.8 \mathrm{~kg} / \mathrm{ha}$, which is $34.8 \%$ lower compared to the previous variant. The total balance is negative in the variants with alsike clover and amounted to $8.2 \mathrm{~kg} / \mathrm{ha}$.

It has been established that phosphorus is the most intensely removed by birdsfoot deer vetch $-320 \mathrm{~kg} / \mathrm{ha}$ and cow clover $-31.0 \mathrm{~kg} / \mathrm{ha}$. Its smallest loss is observed in the variant with alfalfa $(25.5 \mathrm{~kg} / \mathrm{ha})$. Relative to the potassium regime, this food element is the most heavily used by birdsfoot deer vetch $-91.4 \mathrm{~kg} / \mathrm{ha}$. The lowest potassium expenditure is observed in the variant with alfalfa $-71.4 \mathrm{~kg} / \mathrm{ha}$, which, in our opinion, is connected with the yield of the crop grown. The balance of potassium 
in the soil in the variants with legumes when applying potash fertilizers at the rate of $60 \mathrm{~kg} / \mathrm{ha}$ is negative.

\section{References:}

1. Vasileva, V. (2012). Vplyv mineral'noho azotnoho zaplidnennya ta vodno-defitsytnoho stresu na khimichnyy sklad lyutserny [Effect of mineral nitrogen fertilization and water-deficiency stress on chemical composition of lucerne (Medicago sativa L.)]. Proceedings of the 24th General Meeting of the European Grassland Federation. Lublin, Poland 3-7 june 2012. Oficyna Wydawnicza Garmond Poznan. Grassland Science in Europe. Vol. 17. P. 391-393.

2. Sobko, M. H., Sobko, A. N., \& Sobko, O. M. (2012). Rol' bahatorichnykh bobovykh u pidvyshchenni rodyuchosti gruntiv. Vyrobnytstvo kormiv ta kormiv [Perennial legume role in increasing of soil fertility. Forage and fodder production]. Edition 74. P. 53-57.

3. Balayev, A. D., Kovalchuk, O. P., \& Doroshevych, N. F. (2011). Zminy ta zapasy humusu na sirykh lisovykh gruntakh pry vykorystanni riznykh nasinnyevykh kul'tur yak zelenykh dobryv. Vyrobnytstvo kormiv ta kormiv [Content and stock changes of humus in gray forest soils in use of various seed crops as green fertilizers. Forage and fodder production]. Edition 70. P. 106-110.

4. Petrichenko, V. F. (2010). Aktual'ni problemy vyrobnytstva kormiv v Ukrayini [Relevant problems of fodder production in Ukraine]. Herald of Agrarian Science, no 10, pp. 18-21.

5. Tsimbalyuk, V. M. (2000). Rezerv pidvyshchennya rodyuchosti gruntiv ta vyrobnytstva kormiv [Reserve of increasing the soil fertility and forage production]. The village master, no 3-4, pp. 9.

6. Kvitko, H. P., \& Hetman, N. Y. (2003). Yemnist' dlya fiksatsiyi azotu ta zbahachennya gruntu azotom zalezhno vid terminu ekspluatatsiyi Medicago sativa $\mathrm{v}$ umovakh lisostepu [Nitrogen fixing capacity and soil enrichment with nitrogen depending on the lifetime of Medicago sativa in conditions of forest-steppe]. Forage and fodder production, no 51, pp. 54-57.

7. Tsyhanskyi, V. I., Didur, I. M., Tsyhanska, O. I., Malynka, L. V., Butenko, A. O., Masik, I.M., \& Klochkova, T. I. (2019). Vplyv elementiv tekhnolohiyi kul'tyvuvannya na aktyvizatsiyu symbiozu roslynnykh mikrobiv ta protsesy transformatsiyi azotu $\mathrm{v}$ ahrotsenozakh lyutserny [Effect of the cultivation technology elements on the activation of plant microbe symbiosis and the nitrogen transformation processes in alfalfa agrocoenoses]. Modern Phytomorphology, 13: 30-34. doi: https://doi.org/10.5281/zenodo.20190107 